\section{Australian Journal of \\ Crop Science}

\title{
Productivity of soybean crop after fertilization with normal and polymer-coated potassium sources
}

\section{Jéssica Caroline Coppo ${ }^{1}$, Maria Do Carmo Lana ${ }^{2}$, Jussara Carla Conti Friedrich ${ }^{2}$, Alfredo José Alves Neto ${ }^{2}$ Diego August Fatecha Foiz ${ }^{2}$, Jucenei Fernando Frandoloso ${ }^{2}$, Leandro Rampim ${ }^{3}$, Bruna Broti Rissato ${ }^{1}$}

\author{
${ }^{1}$ State University of Maringá- UEM, Campus Maringá, Colombo Avenue, 5790, Centro, CEP: 87020900, Maringá, \\ Paraná State Brazil \\ ${ }^{2}$ West of Paraná State University- Unioeste, Campus Marechal Cândido Rondon, Street Pernambuco, 1777, Postal \\ Code 1008, centro, CEP:85960-000, Marechal Candido Rondon, Paraná State, Brazil \\ ${ }^{3}$ Central Western Paraná State University- UNICENTRO, Campus Guarapuava, Street Salvatore Renna, 875, CEP: \\ 85015430, Garapuava, Paraná State Brazil
}

\begin{abstract}
The adoption of different fertilizer application methods should consider the operational, agronomic and economic aspects. The objective of this work was to study the fertilization response with potassium in the soybean crop at different times of application and different potassium sources in an Eutroferric Red Latosol. The experiment was carried out in the municipality of Formosa do Oeste-PR. The design was in a randomized block in a factorial scheme $(2 \times 5)+1$, with 2 potassium sources: normal $\mathrm{KCl}(\mathrm{KCl})$ and polymer-coated $\mathrm{KCl}\left(\mathrm{KCl}\right.$-polymer), the $\mathrm{KCl}$ doses were adjusted to $40 \mathrm{~kg} \mathrm{ha}^{-1}$ of $\mathrm{K}_{2} \mathrm{O}$, the second factor refers to the splitting of $\mathrm{K}_{2} \mathrm{O}$ dose in five application times: T1, application of $\mathrm{K}_{2} \mathrm{O}$ was nine days before sowing, T2 application split up being $1 / 2$ of the dose nine days before sowing $+1 / 2$ of the dose of $\mathrm{K} 2 \mathrm{O}$ at sowing, T3 application of the total dose of $\mathrm{K}_{2} \mathrm{O}$ at sowing, $\mathrm{T} 4 \mathrm{1} / 2$ of the dose at sowing + $1 / 2$ at the $\mathrm{V} 3$ phenological stage of the crop, T5 application of $\mathrm{K}_{2} \mathrm{O}$ was total at the V3 stage of the crop. And an additional witness, without $\mathrm{K}_{2} \mathrm{O}$ application. $\mathrm{KCl}$-polymer was more efficient for application to the haul before sowing the crop. The fertilization with $\mathrm{KCl}$ was better when applied at the $\mathrm{V} 3$ stage of the crop. Fertilization with $\mathrm{KCl}$-polymer resulted in higher $\mathrm{K}$ content in the leaf, higher efficiency of fertilizer use reflecting in higher productivity.
\end{abstract}

Keywords: Potassium fertilization, times of application, efficiency.

Abbreviations: $\mathrm{K}_{2} \mathrm{O} \_$oxido de potassium, $\mathrm{K} \_$potassium, Al_aluminum, $\mathrm{p} \_$phosphorus, $\mathrm{Ca}$ _calcium, Mg_magnesium, $\mathrm{KCl}$ _potassium chloride,V3_phenological stage of the soybean, S_sulfur, OM_organic matter.

Introduction

The nutrients with the highest annual extraction and replenishment in the soybean crop are $K$ and $P$. The potassium demand for the crop is approximately $38 \mathrm{~kg}$ of $\mathrm{K}_{2} \mathrm{O}$ for each ton of grain (Oliveira Junior, et al., 2013). In the plant, potassium is a mobile element in the phloem redistributing to young meristematic tissues in case of deficiency (Malavolta et al., 1997). It is responsible for the osmotic regulation control of stomata opening, assimilate translocation, nitrogen absorption and protein and starch synthesis, important for grain filling (Taiz and Zeiger, 2004). As source of potassium for mineral fertilization in agriculture, the potassium chloride is most used, with around $90 \%$ of the volume applied to supply the need for potassium in agriculture (Santiago and Rossetto, 2010), besides being the fertilizer with the highest concentration of potassium and also being relatively cheap (Rosolen et al., 2017).

However, pelleted fertilizers currently exist in the market, which can be coated or encapsulated by soluble compounds enveloped by a water-permeable resin that will regulate the nutrient delivery process (Vieira and Teixeira, 2004). In addition to that, factors such as thickness and the chemical nature of the coating resin, the amount of microcracks on its surface and the size of the fertilizer granule determine the release rate of nutrients over time (Girardi and Mourão Filho, 2003).

With the expansion of no-tillage system, there were changes in soybean fertilization, aiming at the availability of nutrients during the periods of greatest crop's need and optimization of sowing in extensive areas, in order to increase productivity associated with better management practices (Silva and Lazarini, 2014).

In the soybean crop, the maximum absorption of potassium occurs during the flowering period (Sfredo, 2008). However, when fertilization is carried out before sowing, the nutrient may not be available for absorption when supplied by the usual source, normal $\mathrm{KCl}$, as a consequence of leaching and soil $\mathrm{K}$ fixation (Rosolem and Steiner, 2017). This fact becomes more worrying when the applied dose is high and carried out in a single application, since water-soluble potassic fertilizers can have deleterious effects on soil fertility and plant growth (Daliparthy et al., 1994).

In order to maximize the productivity of the soybean crop, there is a constant search for formulations and sources of 
fertilizers that present less harmful dynamics to the development of the crop and that are more efficient when throwing is carried out before or after sowing and even at the moment of sowing (Caires and Fonseca, 2000). However, when applied on the line at the time of sowing, it has often led to a reduction in the germination power of the seeds (Bernardi et al., 2009). A similar result was observed by Kawavata et al. (2017), when studying the influence of doses of normal $\mathrm{KCl}$ and coated $\mathrm{KCl}$ in the maize root system and in the electrical conductivity in the soil.

With the objective of comparing time sources and application rates of potassium chloride coated or not coated by polymers on the yield performance of soybean, Guareschi et al. (2011) observed higher dry mass production when using coated $\mathrm{KCl}$ in the anticipated fertilization in the soybean crop in relation to the conventional fertilizer.

Although fertilizers coated with controlled release polymers have been developed and used more and more in the soybean crop, when using them it is necessary to consider some factors such as soil texture, temperature, time of application and economic viability, considering that the fertilization is performed to increase production and profit (Raij, 2011).

In view of the aforementioned, this study aimed at assessing the response of the potassium fertilization in the soybean crop at different times of application and different potassium sources in an Eutrophic Red Latosol.

\section{Results and Discussion}

Plant height, height of insertion of the first pod, mass of 1000 grains and productivity

There was an increase in soybean productivity in response to potassium fertilization when compared to the control, except to the fact that when applying $\mathrm{KCl}$-polymer at $100 \%$ of the dose in the crop V3 stage, the yield did not differ from the control. However, for the $\mathrm{KCl}$ there was no difference in relation to the control when applying $100 \%$ nine days before sowing. The results allow concluding that potassium fertilization in a soil with high potassium content can be efficient depending on the period, form of application and the source used. Serafin et al. (2012) assessed the effect of soil moisture and potassium doses in the soybean crop and found an increase in grain yield, a mass of 100 grains, $K$ content in the grain, in addition to a viable number of pods, and concluded that $\mathrm{K}$ had reduced the effects of the water deficit in soybean.

The results allow concluding that potassium fertilization in a soil with high potassium content can be efficient depending on the time and form of application and the source used. Serafin et al. (2012) evaluated the effect of soil moisture and potassium doses in the soybean crop and found an increase in grain yield, mass of 100 grains, $K$ content in the grain and number of viable pods and concluded that $K$ reduced the effects of the deficit in soybean. The highest productivity was observed when $\mathrm{KCl}$-polymer was split up, being $1 / 2$ nine days before sowing $+1 / 2$ at the moment of sowing. This result can be explained by the fact that this source is mainly developed for early application, a product based on potassium, based on the complexation of two molecules that reduce the salinization process and stimulate the development of radicels. In addition, the granule is protected by a resin that prevents the release of nutrients quickly, reducing the loss of $\mathrm{K}$ by leaching and other nutrients present in the source. These results are different from those observed by Bernardi et al. (2009), who did not find a significant response to soybean yield using doses of 0 , 30,60 and $180 \mathrm{~kg}$ ha- 1 applied in pre-sowing (throwing) and at the moment of sowing with and without cover.

However, there are still few studies available in the literature regarding the study of potassium sources coated with different polymers. There are few studies on the soil dynamics of each product used, the coating degradation rate or its effect on the crop studied. For this reason, there are results that are contradictory to the ones seen in the present experiment. Rodrigues et al. (2014), when studying fertilization with coated- $\mathrm{KCl}$ in the maize crop in Brazilian savanna region showed that the type of polymer used in $\mathrm{KCl}$ was not efficient in the gradual release of $\mathrm{K}$, probably due to the edaphoclimatic conditions of the region, high temperatures and very clay soils, which retain moisture and could have favored the rapid degradation of the coating polymer.

Considering the $\mathrm{KCl}$ source, the highest productivity in relation to the $\mathrm{KCl}$-polymer was obtained when the fertilization was carried out in the V3 crop stage. For a better understanding of this result, it is important to consider that $\mathrm{KCl}$ is a very soluble source in the soil, since it is consists of sylvinite minerals $(\mathrm{KCl})$ and sylvinite $(\mathrm{KCl}+\mathrm{NaCl})$, which are easily solubilized (Nascimento et al., 2008). These data are in agreement with Lana et al. (2002), who, when studying the $\mathrm{K}_{2} \mathrm{O}$ doses split up, especially when applied at the flowering stage, showed significant responses in relation to the total dose at the moment of sowing. Corroborating with results of the present experiment, Luchese et al. (2011) verified maximum grain yield of the soybean crop when using coated polymer $\mathrm{KCl}$ in relation to conventional $\mathrm{KCl}$.

For the $\mathrm{KCl}$-polymer the lower productivity was observed when $100 \%$ of the $\mathrm{K}_{2} \mathrm{O}$ dose was applied at the $\mathrm{V} 3$ stage of the crop with $3839.58 \mathrm{~kg} \mathrm{ha}^{-1}$, which did not differ at $(<0.05)$ from the control. This fact can be explained by the protection mechanism contained in the $\mathrm{KCl}$-polymer granule from which it tends to hinder the entry of water into the granule so that nutrient release does not occur quickly when the precipitation is high in a short period of time, condition that occurred in the present study (Figure 1).

Plant height is a particular characteristic of each cultivar, and the average found in this study was with DM 7166 IPRO cultivar was of $86.51 \mathrm{~cm}$ with $\mathrm{KCl}$-polymer and 85.55 with $\mathrm{KCl}$ (Table 2). According to Sediyama (2009), the desirable target for a more efficient harvest is that the crop should be around 70 to $80 \mathrm{~cm}$. In order to highlight the importance of the variable in soybean yield, Bertolin (2010) stated that amounts next to $85 \mathrm{~cm}$ may favor the plant mechanical harvest. For the $\mathrm{KCl}$-polymer there was higher plant height when $100 \%$ of the dose was applied at the V3 stage of the culture when lower productivity was observed. For $\mathrm{KCl}$, the management that provided the highest plant height was when applied to the total dose nine days before sowing $89.07 \mathrm{~cm}$, not statistically different from the other treatments, only from the control. This result is close to values found by Bertolin et al. (2010) with the cultivar Conquista and obtained higher plant heights, reaching 86.78. Regarding the insertion height of the first pod, there was no statistical difference (Table 3). According to Finoto et 
Table 1. Chemical attributes of the samples collected before the setting up of the experiment.

\begin{tabular}{|c|c|c|c|c|c|c|c|c|c|c|}
\hline Depth & $P$ & OM & $\mathrm{H}+\mathrm{Al}$ & $\mathrm{Al}^{3+}$ & $\mathrm{K}^{+}$ & $\mathrm{Ca}$ & $\mathrm{Mg}^{2+}$ & SB & CEC & V \\
\hline & $\mathrm{mg} \mathrm{dm}^{-3}$ & $\mathrm{~g} \mathrm{dm}^{-3}$ & ------ & -----. & $\mathrm{smol}_{\mathrm{c}} \mathrm{c}$ & & & 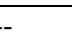 & & $\%$ \\
\hline $0-10 \mathrm{~cm}$ & 16.45 & 23.24 & 3.21 & 0.10 & 0.33 & 4,58 & 1.18 & 6.1 & 9.40 & 65 \\
\hline $10-20 \mathrm{~cm}$ & 14.12 & 18.12 & 2.80 & 0.30 & 0.3 & 2,30 & 1.30 & 3.83 & 6.63 & 58 \\
\hline
\end{tabular}

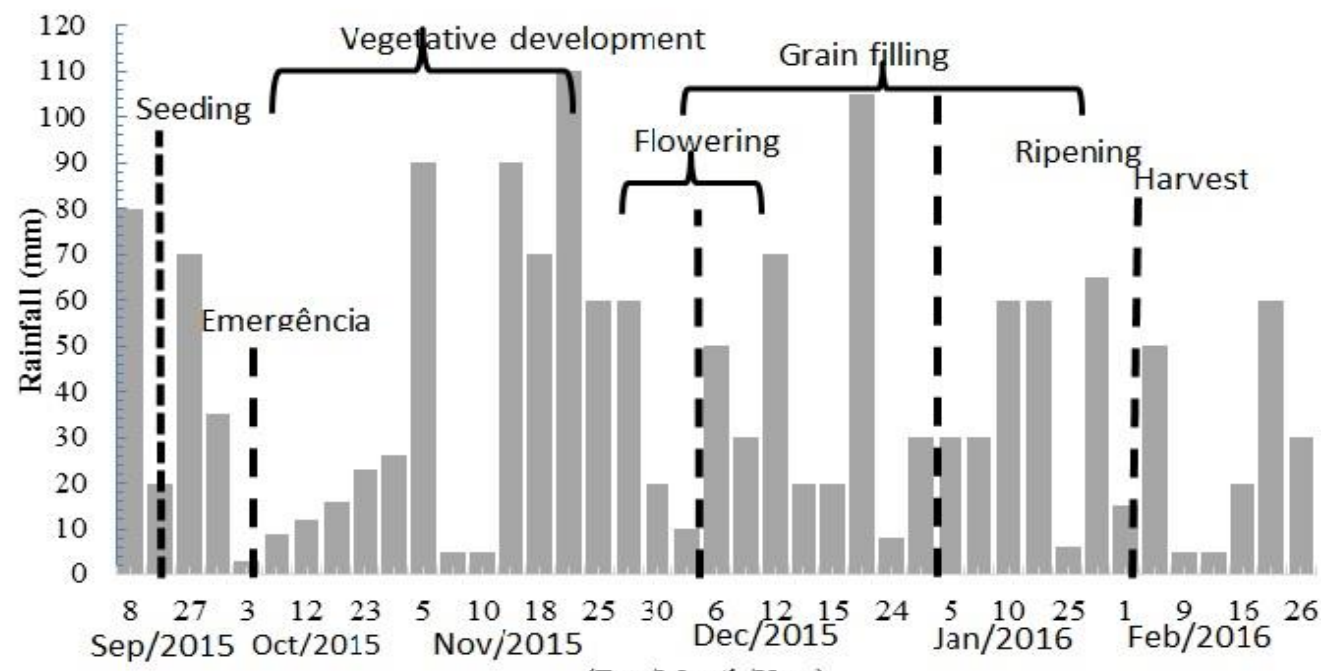

(Day/Month/Year)

Fig 1. Daily precipitation for the experiment site during the 2015/2016 soybean harvest.

Table 2. Plants height, height of first pod insertion, mass of 1000 grains and soybean yield in function of the mode of application of potassium fertilizer with the source $\mathrm{KCl}$-polymer and $\mathrm{KCl}$ in the $2015 / 2016$ harvest.

\begin{tabular}{|c|c|c|c|c|}
\hline \multirow[t]{2}{*}{ Treatment } & \multicolumn{2}{|l|}{ Plant height } & \multicolumn{2}{|l|}{ Pod height } \\
\hline & $\mathrm{KCl}$-polymer & $\mathrm{KCl}$ & $\mathrm{KCl}$-polymer & $\mathrm{KCl}$ \\
\hline \multicolumn{5}{|c|}{ 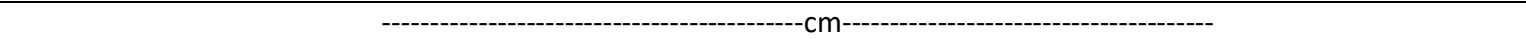 } \\
\hline $100 \%$ (9 DBS) & 91.30Aab ${ }^{*}$ & 89.07Aa ${ }^{*}$ & 15.70Aa & 15.90Aa \\
\hline $1 / 29$ DBS $+1 / 2$ SOW & $84.65 \mathrm{Abc}$ & $88.40 \mathrm{Aa}$ & 15.95Aa & 16.75Aa \\
\hline $100 \%$ SOW & 84.80Abc & 85.64Aa & $15.60 \mathrm{Aa}$ & 15.90Aa \\
\hline $1 / 2 \mathrm{SOW}+1 / 2 \mathrm{~V} 3$ & 82.00Ac & $82.52 \mathrm{Aa}$ & 15.40Aa & $16.45 \mathrm{Aa}$ \\
\hline $100 \% \mathrm{~V} 3$ & $96.45 \mathrm{Aa}^{*}$ & 87.17Ba & 16.90Aa & $15.55 \mathrm{Aa}$ \\
\hline Control & \multicolumn{2}{|l|}{80.50} & \multicolumn{2}{|l|}{15.15} \\
\hline Average & 87.84 & 86.56 & 15.91 & 16.11 \\
\hline \multirow[t]{2}{*}{ Treatment } & \multicolumn{2}{|c|}{ Mass of 1000 Grains } & \multicolumn{2}{|l|}{ Productivity } \\
\hline & KCl-polymer & $\mathrm{KCl}$ & $\mathrm{KCl}$-polymer & $\mathrm{KCl}$ \\
\hline \multicolumn{5}{|c|}{ 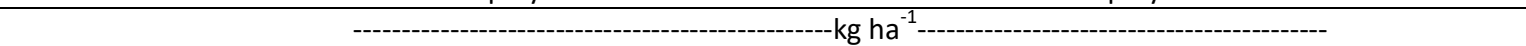 } \\
\hline $100 \%$ (9 DBS) & $95.86 \mathrm{Ab}^{*}$ & $93.01 \mathrm{Bb}$ & 4190.00 Aab ${ }^{*}$ & $3991.80 \mathrm{Bb}$ \\
\hline $1 / 29$ DBS $+1 / 2$ SOW & $99.98 \mathrm{Aa}^{*}$ & $95.2 \mathrm{Bab}^{*}$ & $4472.77 \mathrm{Aa}^{*}$ & $3953.33 \mathrm{Bab}^{*}$ \\
\hline $100 \%$ SOW & $94.12 \mathrm{Ab}$ & $95.2 \mathrm{Aab}^{*}$ & $4076.38 \mathrm{Ab}^{*}$ & $3978.33 \mathrm{Aab}^{*}$ \\
\hline $1 / 2$ SOW $+1 / 2$ V3 & $94.12 \mathrm{Ab}$ & $96.3 \mathrm{Aab}^{*}$ & 4149.44 Aab ${ }^{*}$ & $4051.52 \mathrm{Aa}^{*}$ \\
\hline $100 \% \mathrm{~V} 3$ & $94.14 \mathrm{Bb}$ & $98.69 \mathrm{Aa}^{*}$ & $3839.58 \mathrm{Bb}$ & $4047.63 \mathrm{Aa}^{*}$ \\
\hline Control & 88.85 & & 3687,77 & \\
\hline Average & 95.64 & 95.68 & 4165.63 & 3984.52 \\
\hline
\end{tabular}

averages that differ from the control by using Dunnett test, at 5\% probability. DBS: Day before sowing; SOW: Sowing; V3: Phenological stage of soybean crop. 
Table 3. Fixed cost and variable cost of production, gross and net revenue from soybean production according to the different forms of application of $\mathrm{KCl}$-polymer and $\mathrm{KCl}$, in the 2015/2016 harvest.

\begin{tabular}{|c|c|c|c|c|c|c|c|c|c|}
\hline & \multirow[t]{2}{*}{ Fixed cost } & \multicolumn{2}{|c|}{ Variable cost } & \multicolumn{2}{|c|}{ Total cost } & \multicolumn{2}{|c|}{ Gross revenue } & \multicolumn{2}{|c|}{ Net revenue } \\
\hline & & $\begin{array}{l}\mathrm{KCl}- \\
\text { polymer }\end{array}$ & $\mathrm{KCl}$ & $\begin{array}{l}\mathrm{KCl}- \\
\text { polymer }\end{array}$ & $\mathrm{KCl}$ & $\begin{array}{l}\mathrm{KCl}- \\
\text { polymer }\end{array}$ & $\mathrm{KCl}$ & $\begin{array}{l}\mathrm{KCl}- \\
\text { polymer }\end{array}$ & $\mathrm{KCl}$ \\
\hline & -----. & & -1--on & $\mathrm{R} \$ \mathrm{ha}^{-1}$ & 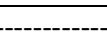 & & ---------- & - & \\
\hline $\begin{array}{l}100 \% \quad(9 \\
\text { DBS) }\end{array}$ & 1445.9 & 502.6 & 325.9 & 1948.4 & 1771.7 & 4419.0 & 3591.8 & 2231.6 & 1820.1 \\
\hline $\begin{array}{l}1 / 29 \text { DBS + } \\
1 / 2 \text { SOW }\end{array}$ & 1445.9 & 502.6 & 325.9 & 1948.4 & 1771.7 & 4472.8 & 3953.3 & 2524.4 & 2181.6 \\
\hline $100 \%$ SOW & 1445.9 & 492.6 & 492.6 & 1938.4 & 1761.7 & 4076.4 & 3978.3 & 2138.0 & 2216.6 \\
\hline $\begin{array}{l}1 / 2 \text { SOW }+ \\
1 / 2 \text { V3 }\end{array}$ & 1445.9 & 502.6 & 325.9 & 1948.4 & 1771.7 & 4149.4 & 4051.5 & 2201.0 & 2279.8 \\
\hline $100 \%$ V3 & 1445.9 & 502.6 & 325.9 & 1948.4 & 1771.7 & 3839.6 & 4247.6 & 1891.2 & 2475.9 \\
\hline Control & 1445.9 & & & 1445.9 & & 3686.8 & & 2019.4 & \\
\hline
\end{tabular}

DBS: Day before sowing; SOW: Sowing; V3: Phenological stage of soybean crop. Variable cost: Operation with machines, maintenance expenses, temporary labor, se ed, fertilizer, pesticides, transportation, technical assistance, pro-rage and interest. Total cost: Variable cost + cost with the fertilization of KCl and haul application operation. Gross revenue: Productivity in $60 \mathrm{~kg}$ bag ha ${ }^{-1}$ multiplied by the value of $60 \mathrm{~kg}$ bag quoted at the time of harvest $(\mathrm{R} \$ 60.00)$.

Table 4. Potassium content in the leaf and in the grain with the sources $\mathrm{KCl}$-polymer and $\mathrm{KCl}$ in soybean crop in the $2015 / 2016$ harvest.

\begin{tabular}{|c|c|c|c|c|}
\hline \multirow[t]{2}{*}{ Treatment } & \multicolumn{2}{|c|}{$\mathrm{K}$ content in the leaf } & \multicolumn{2}{|c|}{$\mathrm{K}$ content in the grain } \\
\hline & KCl-polymer & $\mathrm{KCl}$ & $\mathrm{KCl}$-polymer & $\mathrm{KCl}$ \\
\hline \multicolumn{5}{|c|}{ - } \\
\hline $100 \%$ (9 DBS) & $16.66 \mathrm{Aab}^{*}$ & $15.67 \mathrm{Aa}$ & $15.25 \mathrm{Aab}^{*}$ & $14.96 \mathrm{Ab}^{*}$ \\
\hline $1 / 29$ DBS $+1 / 2$ SOW & $17.46 \mathrm{Aa}^{*}$ & $15.62 \mathrm{Ba}$ & $15.75 \mathrm{Aa}^{*}$ & 13.96Bab \\
\hline $100 \%$ sow & 16.16Aab & 16.34Aa & $16.09 \mathrm{Aa}^{*}$ & $15.45 \mathrm{Ba}^{*}$ \\
\hline $1 / 2$ SOW $+1 / 2$ V3 & $15.19 A b$ & $15.50 \mathrm{Aa}$ & $14.46 \mathrm{Bb}^{*}$ & $15.69 \mathrm{Aa}^{*}$ \\
\hline $100 \% \mathrm{~V} 3$ & $16.50 \mathrm{Aa}^{*}$ & $17.34 \mathrm{Aa}^{*}$ & $15.17 \mathrm{Aa}^{*}$ & $15.50 \mathrm{Aa}^{*}$ \\
\hline Control & \multicolumn{2}{|c|}{14.75} & \multicolumn{2}{|c|}{12.93} \\
\hline Average & 16.39 & 16.09 & 15.34 & 15.11 \\
\hline
\end{tabular}

Table 5. Potassium content in the soil in the $0-10$ and $10-20 \mathrm{~cm}$ layer, collected after soybean harvest in the 2015/2016 harvest.

\begin{tabular}{|c|c|c|c|c|}
\hline \multirow[t]{2}{*}{ Treatment } & \multicolumn{2}{|c|}{$\mathrm{K}$ content in the $0-10 \mathrm{~cm}$ soil } & \multicolumn{2}{|c|}{$\mathrm{K}$ content in the $10-20 \mathrm{~cm}$ soil } \\
\hline & $\mathrm{KCl}$-polymer & $\mathrm{KCl}$ & $\mathrm{KCl}$-polymer & $\mathrm{KCl}$ \\
\hline & \multicolumn{4}{|c|}{ - } \\
\hline $100 \%$ (9 DBS) & $0.27 \mathrm{Ab}$ & $0.25 \mathrm{Aa}$ & $0.20 \mathrm{Aa}$ & $0.22 \mathrm{Aa}$ \\
\hline $1 / 29$ DBS $+1 / 2$ SOW & $0.27 \mathrm{Ab}$ & $0.28 \mathrm{Aa}$ & $0.20 \mathrm{Aa}$ & $0,18 \mathrm{Aa}$ \\
\hline $100 \%$ DBS & $0.34 \mathrm{Aab}^{*}$ & $0.31 \mathrm{Aa}^{*}$ & $0.24 \mathrm{Aa}$ & $0.28 \mathrm{Aa}$ \\
\hline $1 / 2$ SOW + $1 / 2$ V3 & $0.32 \mathrm{Aa}^{*}$ & $0.27 \mathrm{Ba}^{*}$ & $0.22 \mathrm{Aa}$ & $0.22 \mathrm{Aa}$ \\
\hline $100 \% \mathrm{~V} 3$ & $0.34 \mathrm{Aa}^{*}$ & $0.26 \mathrm{Ba}$ & $0.22 \mathrm{Aa}$ & $0.21 \mathrm{Aa}$ \\
\hline Control & \multicolumn{2}{|c|}{0.21} & \multicolumn{2}{|c|}{0.16} \\
\hline Average & 0.30 & 0.28 & 0.22 & 0.22 \\
\hline
\end{tabular}

The averages followed by the same capital letter in the row and lowercase in the column do not differ among them by using Tukey's test $5 \%$ of probability. ${ }^{*}$ The averages that differ from the control by using Dunnett test, at $5 \%$ probability. DBS: Day before sowing; Sow: Sowing; V3: Phenological stage of soybean crop.

Table 6. Averages efficiency of the potassium use in the grain (EKUG), efficiency of the fertilizer use (EFU) and efficiency of the nutrient recovery (ENR) in soybean plants, according to the different forms of application of KCl-polymer and $\mathrm{KCl}$ in the 2015/2016 harvest.

\begin{tabular}{|c|c|c|c|c|c|c|c|c|c|}
\hline & \multicolumn{3}{|l|}{ EUKG } & \multicolumn{3}{|l|}{ EFU } & \multicolumn{2}{|l|}{ ENR } & \multirow[b]{2}{*}{ Mean } \\
\hline & $\mathrm{KCl}$-polymer & $\mathrm{KCl}$ & Mean & $\mathrm{KCl}$-polymer & $\mathrm{KCl}$ & Mean & $\mathrm{KCl}$-polymer & $\mathrm{KCl}$ & \\
\hline \multicolumn{7}{|c|}{ 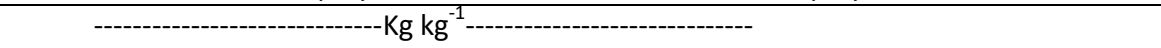 } & \multicolumn{2}{|c|}{---------------\%------------. } & \\
\hline $100 \%$ (9 DBS) & 274.75Aa & $240.09 \mathrm{Aa}$ & 257.42 & $15.15 \mathrm{Ab}$ & $10.26 \mathrm{Bb}$ & 12.70 & 45.94Aa & $45.07 \mathrm{Aa}$ & 45.50 \\
\hline $1 / 2$ DBS $(1 / 2$ SOW $)$ & $283.98 \mathrm{Aa}$ & $283.18 \mathrm{Aa}$ & 283.58 & $23.65 \mathrm{Aa}$ & $12 \mathrm{Bb}$ & 17.82 & 47.45 Aa & $42.06 \mathrm{Aa}$ & 44.75 \\
\hline $100 \%$ SOW & $253,34 \mathrm{Aa}$ & $257.49 \mathrm{Aa}$ & 255.41 & $11.73 \mathrm{Ac}$ & $8.75 \mathrm{Ab}$ & 10.24 & $48.47 \mathrm{Aa}$ & $46.55 \mathrm{Aa}$ & 47.51 \\
\hline $1 / 2$ SOW $1 / 2$ V3 & $286.95 \mathrm{Aa}$ & 258.22 Aa & 272.58 & $13.90 \mathrm{Abc}$ & $10.95 \mathrm{Bb}$ & 12.42 & $43.56 \mathrm{Aa}$ & 47.27 Aa & 45.41 \\
\hline $100 \%$ V3 & $253.10 \mathrm{Aa}$ & $274.04 \mathrm{Aa}$ & 263.57 & $4.57 \mathrm{Bbc}$ & 16.86Aa & 10.71 & $45.70 \mathrm{Aa}$ & $46.70 \mathrm{Aa}$ & 46.20 \\
\hline Average & 270.42 & 262.60 & 266.51 & 34.5 & 11.76 & 12.77 & 46.22 & 45.53 & 45.87 \\
\hline
\end{tabular}

The averages followed by the same capital letter in the row and lowercase in the column do not differ among them by using Tukey's test at 5\% of probability. DBS: Day before sowing; SOW: Sowing; V3: Phenological stage of soybean crop. 
al. (2011), the height of the first pod insertion is the most important factor in the soybean mechanized harvesting. Therefore, in order to make the crop economically viable, it is recommended that the cultivar used has an insertion height of the first pod between 10 and $20 \mathrm{~cm}$ high.

\section{Economic analysis}

When economically analyzing, the highest yield obtained from each source in relation to the production cost per hectare, for the $\mathrm{KCl}$-polymer source, was when it produced $4472.77 \mathrm{~kg} / \mathrm{ha}$ and obtained a production cost of approximately $\mathrm{R} \$ 1948.41 \mathrm{ha}^{-1}$, which allowed a net revenue of $\mathrm{R} \$ 2524.3 \mathrm{ha}^{-1}$, compared to the highest productivity of the $\mathrm{KCl}$ of $4247.63 \mathrm{~kg} \mathrm{ha}^{-1}$ with a net revenue of $\mathrm{R} \$ 2475.36$ (Table 3). The net revenue of the control was of R\$2019.36 when compared to the total dose application at sowing, whose net revenue was of $\mathrm{R} \$ 2137.36$ and $\mathrm{R} \$ 2216.60$ for $\mathrm{KCl}$-polymer and $\mathrm{KCl}$, respectively. Considering the condition of the present study, it was seen that the application of $100 \% \mathrm{KCl}$ at the time of sowing obtained a superior profit of $\mathrm{R} \$ 78.63$ in relation to the $\mathrm{KCl}$-polymer source. The high cost actually seems to be the main limitation for using $\mathrm{KCl}$ polymer, since agronomically the product has surpassed the source of $\mathrm{K}_{2} \mathrm{O}$ commonly used.

As for the $\mathrm{KCl}$-polymer, the lower productivity was found when $100 \%$ of the dose of K2O was applied in the V3 stage of the crop, with a net revenue of $\mathrm{R} \$ 1891.17$ which was $\mathrm{R} \$$ 128.19 lower than the control. In view of this result, it is important to consider at the time of application of the fertilizer its agronomic efficiency and its financial return, either in the reduction of the volume used, in the acquisition cost per nutrient point, or in the productivity gain.

When $\mathrm{KCl}$ was applied $100 \%$ nine days before sowing, it obtained net revenue of $\mathrm{R} \$ 1820.07$, being the net revenue lower than the control in $\mathrm{R} \$ 1$ 199.29. Therefore, it can be affirmed that under the conditions of the present study, with the soil potassium content of $0.33 \mathrm{cmolc} d \mathrm{~m}-3$ the anticipated application of normal $\mathrm{KCl}$ is not economically feasible.

\section{Potassium content in the leaf and in the grain}

In relation to the nutrient content in the leaf tissue, when applying the $\mathrm{KCl}$-polymer source $1 / 2$ nine days before sowing $+1 / 2$ at the moment sowing, the potassium content in the leaf was higher $\left(17.46 \mathrm{~g} \mathrm{~kg}^{-1}\right)$, coinciding with the higher mass of 1000 grains and productivity (Table 4). The gradual potassium release from $\mathrm{KCl}$-polymer, when applied in advance into the soil, provided the amount of $K$ available in the soil compatible with the soybean crop demand, with a less possibility of losing potassium by leaching, and keeping the supply of $\mathrm{K}$ necessary to meet the plant demand. The same occurred with the $\mathrm{KCl}$ source when applied $100 \%$ in the crop V3 stage, where it could be observed the highest potassium content in the leaf of $17.34 \mathrm{~g} \mathrm{~kg}^{-1}$ and the highest yield. A similar result was obtained by Keogh et al. (1972) when comparing nutrient foliar concentrations of ten different maturation group varieties grown under two levels of soil fertility. The authors obtained higher potassium leaf concentrations in the most productive variety tested $(22.0 \mathrm{~g}$ $\mathrm{kg}^{-1}$ ).
The assessment of the data concerning the potassium content in the grain showed that when using the $\mathrm{KCl}$ split up by $1 / 2$ nine days before sowing $+1 / 2$ at sowing, $100 \%$ at sowing and $100 \%$ at the crop V3 stage, the potassium contents for these treatments were higher than those seen for the control. Still referring to $\mathrm{KCl}$, the lowest yields of soybean in this work were observed when the lowest potassium contents were observed in the grain, contrary to those observed by Zambiazi (2014) who, when studying the application of potassium fertilization in the soybean crop, did not observe effect of the season of potassium application in soybean crop cover for grain yield, agronomic characteristics and potassium content in the grain.

\section{Potassium content in the soil}

According to the results shown in table 5 , it is observed that when fertilizing is carried out with the $\mathrm{KCl}$ spit up $1 / 2$ at the moment of sowing $+1 / 2$ at the soybean crop V3 stage and $100 \%$ at the crop V3 stage, the residual potassium content in the soil was lower than that observed with $\mathrm{KCl}$-polymer; however, for the $\mathrm{KCl}$-polymer these treatments provided a higher residual potassium content in the soil but yield was lower, indicating that the potassium release from this fertilizer occurred more slowly and was not compatible with the requirement of the crop when applied at a later stage of the crop development.

However, when both sources were applied nine days before sowing and split up $1 / 2$ nine days before sowing $+1 / 2$ at the moment of sowing, they provided a lower potassium content available in the soil. Considering $\mathrm{KCl}$, lower yields were seen in these periods and forms of application, whereas $\mathrm{KCl}$-polymer obtained a higher yield, which makes evident the efficiency of the throwing application of $\mathrm{KCl}$ polymer, because when this polymer was applied before sowing, it allowed the release of the available potassium to meet the period of greatest demand of the nutrient by the crop.

In the $10-20 \mathrm{~cm}$ soil layer, there was no difference between the sources and the managements for the available potassium content, being all of them considered medium. In the present study, it can be seen that there is a decrease in the potassium contents even in clay soils, since this nutrient is exported by the grain production (Oliveira Junior, et al., 2013).

The reduction of the available potassium contents in areas under successive soybean crop has occurred even when amounts from 33 to $66 \mathrm{~kg} \mathrm{ha}^{-1}$ of potassium have been applied annually (Borkert et al., 1997a).

\section{Efficiency of potassium use in the grain, efficiency of fertilizer use and nutrient recovery efficiency}

Table 6 shows that there was no difference in the efficiency of the potassium use in the grain (EKUG), which represents the grain yield obtained per unit of accumulated nutrient and efficiency of the nutrient recovery (ENR), both between sources, or between different managements within each source.

For fertilizer use efficiency (EFU) when using the $\mathrm{KCl}$-polymer source applied $1 / 2$ nine days before sowing and $1 / 2$ at sowing, EFU was higher than the other treatments, which corroborated with the higher productivity. The same 
occurred with normal $\mathrm{KCl}$ when applied at stage $\mathrm{v} 3$ of the culture. When comparing the two sources, the $\mathrm{KCl}$-polymer showed higher EFU than conventional $\mathrm{KCl}$ when applied $100 \%$ nine days before sowing and also $100 \%$ at the V3 stage of the culture. Some studies indicate superior efficiency of encapsulated potassic fertilizers as in Luchese et al. (2011), who observed higher efficiency of potassium fertilization in sandy textured soils when using polymer-coated $\mathrm{KCl}$ compared to normal $\mathrm{KCl}$.

\section{Materials and Methods}

The experiment was installed in a property of the municipality of West Formosa, with the following geographical coordinates: Longitude: 5318'45" W and latitude: $24017^{\prime} 34 " \mathrm{~S}$ at $420 \mathrm{~m}$ of altitude. The soil of the experiment site is classified as Eutroferric Red Latosol (EMBRAPA, 2013). The granulometric characteristics of the soil are: $660 \mathrm{~g} \mathrm{~kg}^{-1}$ of clay, $130 \mathrm{~g} \mathrm{~kg}^{-1}$ of sand and $210 \mathrm{~g} \mathrm{~kg}^{-1}$ of silt. The chemical attributes of the soil are shown in Table 1.

\section{Experimental design}

A randomized block design in a factorial scheme $(2 \times 5)+1$ was used, with 2 sources of potassium, conventional $\mathrm{KCl}$ (00-00$60)$ and polymer-coated $\mathrm{KCl}$ ( $\mathrm{KCl}$-polymer) in the formula ( $40 \% \mathrm{~K} 2 \mathrm{O}, 3 \% \mathrm{Ca}$ and $3 \% \mathrm{~S}$ ). The polymer used for coating the fertilizer is an amphiphilic compound, which favors an immediate reaction of repulsion of the water in high concentration in the soil around the fertilizer granule resulting from its hydrophobic character, although it maintains some permeability due to its hydrophilic character (Urrutia et al., 2018). Also included in the composition of this fertilizer, there are two ACP COMPLEX molecules, with the function of promoting lower salinity and reducing potassium and residual leaching in the soil, as well as AZAL 5, which is used in order to promote the protection of radicels. Five forms of subdivision of the potassium fertilization are described below.

In the first treatment the application of $\mathrm{K}_{2} \mathrm{O}$ was carried out nine days before sowing (T1), in the second treatment the application was split up, being $1 / 2$ of the dose nine days before sowing $+1 / 2$ of the dose of $\mathrm{K}_{2} \mathrm{O}$ at the moment of sowing (T2). In the third treatment (T3), the application of the complete dose was carried out, while in the fourth treatment (T4) $1 / 2$ of the dose at sowing $+1 / 2$ in the V3 phenological stage of the crop. In the fifth treatment (T5), the application of $\mathrm{K}_{2} \mathrm{O}$ was carried out totally in the $\mathrm{V} 3$ stage of the crop and there was also an additional witness without $\mathrm{K}_{2} \mathrm{O}$ application.

The sowing was carried out on $26^{\text {th }}$ September, 2015, by sowing 13 seeds per meter of arly cycle DM7166 IPRO cultivar. The plots had dimensions of $4 \mathrm{~m}$ wide and $7 \mathrm{~m}$ long, each plot consisted of 4 spaced rows of $0.45 \mathrm{~m}$, from which $5 \mathrm{~m}$ of the two central rows of each plot were used for the assessments. For the treatments in which the fertilization was carried out in the planting groove, a line was manually opened next to the sowing line for the addition of the fertilizer to the depth of $5 \mathrm{~cm}$ below the seed. Considering the treatments with potassium fertilizers before sowing and at the crop V3 stage, a broadcast application was carried out.
In total, the experiment consisted of 44 plots, being all the treatments fertilized with $60 \mathrm{~kg}$ of $\mathrm{P}_{2} \mathrm{O}_{5}$ on the base with simple superphosphate ( $18 \%$ of $\mathrm{P}_{2} \mathrm{O}_{5}, 16 \%$ of $\mathrm{Ca}$ and $5 \% \mathrm{~S}$ ), and the potassium dose was of $40 \mathrm{~kg}$ of $\mathrm{K}_{2} \mathrm{O}$, as a result of the soil analysis and in accordance with the fertilizing recommendation for the crop (SBSC, 2017). For both sources, the potassium and phosphorus doses were the same for all the treatments involving the factorial; however, in the treatments in which the potassium application was split up, the dose of $40 \mathrm{~kg}$ of $\mathrm{K}_{2} \mathrm{O}$ was also split up, that is, 20 $\mathrm{kg}$ of $\mathrm{K}_{2} \mathrm{O}$ in the first application plus $20 \mathrm{~kg}$ of $\mathrm{K}_{2} \mathrm{O}$ in the second application. The precipitation recorded at the experiment site during the period of the study is shown in Figure 1.

\section{Assessed characteristics}

After the harvest, some soil samples were collected at 0-10 and $10-20 \mathrm{~cm}$ depth in order to determine the soil potassium content. Productivity, mass of a thousand grains, plants height, insertion height of the first pod, foliar potassium content, and potassium content in the grain were evaluated. For the chemical analysis of the $\mathrm{K}$ content, the methodology described by Malavolta et al. (1997) was used. And lastly it was accomplished the economic viability of each treatment.

\section{Economic evaluation}

The economic evaluation of each treatment was performed by considering the fixed cost, variable cost, total cost, and the gross and net revenue. The fixed cost of each treatment was considered for estimating the amount of $R \$ 1445.86$ (SEAB, 2016). In order to determine the costs of the plots, the cost with super simple fertilizers (00-19-00) was determined at $\mathrm{R} \$ 980.00$ per ton, with an applied dose of $222.22 \mathrm{~kg} \mathrm{ha}^{-1}$, that is, $\mathrm{R} \$ \mathbf{2 1 7 . 7 7}$ per hectare.

Considering the treatments that received potassium supplementation in soybean crop, the amount of $\mathrm{R} \$ 2700.00$ per ton of the polymer-coated $\mathrm{KCl}$ fertilizer $\left(40 \% \mathrm{~K}_{2} \mathrm{O} 3 \% \mathrm{Ca}\right.$ $3 \%$ S) was adopted, with a total estimated cost of $\mathrm{R} \$ 274.78$. This cost corresponds to the applied dose of $100 \mathrm{~kg} \mathrm{ha}^{-1}$.

Regarding the treatments with $\mathrm{KCl} 00-00-60$, the amount of $\mathrm{R} \$ 1400.00$ per ton was adopted, with a total estimated cost of $\mathrm{R} \$ 98.10$. This cost corresponds to $66.66 \mathrm{~kg} \mathrm{ha}^{-1}$. The treatments that received application of $\mathrm{KCl}$-polymer and broadcast $\mathrm{KCl}$ had the addition of $\mathrm{R} \$ 10.00$ per hectare in relation to the operation cost. Therefore, considering a calculation basis, a variable cost from $R \$ 502.55$ to $R \$ 325.87$ was considered for the treatments that received $\mathrm{KCl}$ polymer and thrown $\mathrm{KCl}$ and from $\mathrm{R} \$ 492.55$ to $\mathrm{R} \$ 325.97$ for those receiving $\mathrm{KCl}$-coated and $\mathrm{KCl}$ at sowing. The total revenue cost for each treatment that received $\mathrm{KCl}$-polymer and thrown $\mathrm{KCl}$ was of $\mathrm{R} \$ 1948.41$ and $\mathrm{R} \$ 1771.73$. These are the costs for the treatments that received the sources at the time of sowing: $\mathrm{R} \$ 1938.41$ and $\mathrm{R} \$ 1761.73$ for the $\mathrm{KCl}-$ polymer and $\mathrm{KCl}$, respectively.

Finally, the efficiency of the use of potassium nutrient were calculated according to the rates proposed by Moll et al. (1982) and Siddiqi and Glass (1981).

a) Efficiency of the use of the nutrient in the grain (EUNg) = grain production $(\mathrm{Y})$ in relation to amount of nutrient in grains (ANg). 


$$
\operatorname{EUNg}\left(\mathrm{kg} \mathrm{kg}^{-1}\right)=\frac{y}{A N g}
$$

b) Efficiency of the fertilizer use (EFU) = grain producton $(\mathrm{Y})$ - grain production of the control $(Y c)$ in relation to the amount of nutrient applied (ANa).

$$
E F U\left(k g k g^{-1}\right)=\frac{y-y c}{A N a}
$$

C) Efficiency of the nutrient recovery $(E N R)=$ Nutrient absorbed in the grain $(\mathrm{ANg})$ in relation to the amount of nutrient applied (ANa).

$$
\operatorname{ENR}(\%)=\frac{A N g}{A N a} * 100
$$

\section{Conclusion}

The potassium fertilization management for soybean crop with normal $\mathrm{KCl}$ and $\mathrm{KCl}$-polymer influenced the productivity and the yield components, and it depends on the plots and period of application. The fertilization with $\mathrm{KCl}$-polymer split up $1 / 2$ nine days before sowing $+1 / 2$ at the moment of sowing provided a greater mass of 1000 grains, potassium content in the leaf and also a higher productivity. The efficiency of fertilizer use is influenced by the peculiar characteristics of each source to decide when and how to apply it, in order to maximize productivity.

\section{References}

Bernardi ACC, Oliveira Júnior JP, Leandro WM, Mesquita TGS, Freitas PL, Carvalho MCS (2009) Doses e formas de aplicação da adubação potássica na rotação soja, milheto e algodão em sistema de plantio direto. Pesq Agropec Trop. 39:158-167.

Bertolin DC,Sá ME, ARF O, Furlani Junior E, Colombo AS, Carvalho FLBM (2010) Aumento da produtividade de soja com a aplicação de bioestimulantes. Bragantia. 69: 339347.

Borkert CM, Farias JRB, Sfredo GJ, Tutida F, Spoladori CL (1997a) Resposta da soja à adubação e disponibilidade de potássio em Latossolo Roxo Álico. Pesq Agropec Bras. 32:1009-1022.

Caires EF, Fonseca AF (2000) Absorção de nutrientes pela soja cultivada no sistema de plantio direto em função da calagem na superfície. Bragantia. 59: 213-220.

Daliparthy J, Barker AV, Mondal SS (1994) Potassium fractions with other nutrients in crops: A review focusing on the tropics. J Plant Nutr.17: 1859-1886.

Embrapa- Empresa Brasileira de Pesquisa Agropecuária (2013) Centro Nacional de Pesquisa de Solos. Sistema brasileiro de classificação de solos. 3. ed. Brasília: Embrapa. 353p.

Finoto EL,Carrega WC, Sediyama T, Albuquerque JAA, Cecon PR, Reis MS (2011) Efeito da aplicação de fungicida sobre caracteres agronômicos e severidade das doenças de final de ciclo na cultura da soja. Agro@mbiente. 5:44-49.

Guareschi RF, Gazolla PR, Perin A, Santini Jmk (2011) Adubação antecipada na cultura da soja com superfosfato triplo e cloreto de potássio revestido por polímeros. Ciência Agrotec. 35: 643-648.

Girardi, EA, Mourão Filho FAA (2003) Emprego de fertilizantes de liberação lenta na formação de pomares de citros. Rev Laranja. 24: 507-518.

Kawavata, C.K.H.; Fois, D.A.F, Coppo, J.C. Alves Neto, A (2017) Influência de doses e de duas fontes de potássio no sistema radicular do milho e na condutividade elétrica no solo. Investigação Agrária. 19: 28-34.

Keogh J.L, Sabbe WE, Caviness CE (1972) Nutrient concentration of selected soyben cultivars. Commun Soil Science Plant Anal. 3: 29-35.

Lana RMQ, Hamawaki OT, Lima LML, Júnio Lazl (2002) Resposta da soja a dose e modos de aplicação de potássio em solo de cerrado. Bioscience J. 18:17-23.

Luchese KUO, Leal AJF, Kaneko FH, Valderrama M, Severino, U.A. Resposta da cultura da soja a doses de cloreto de potássio, revestido ou não com polímeros. In: congresso brasileiro de ciência do solo. 33 Uberlândia. Anais... Viçosa: SBCS, 2011. CD-Rom.

Malavolta E, Vitti GC, Oliveira AS (1997) Avaliação do estado nutricional das plantas: princípios e aplicações. 2.ed. Piracicaba. POTAFÓS.

Moll RH, Kampra TH EJ, Jackson WA (1982) Analysis and interpretation of factors which contribute to efficiency of nitrogen utilization. Agronomy J. 74:56 -565.

Nascimento M, Monte MBM, Loureiro FEL (2008) Agrominerais: potássio. In: LUZ, A. LINS FAF. Rochas e minerais industriais. 2. ed. Rio de Janeiro: Cetem. p. 175205.

Oliveira Junior A, Castro CD de, Oliveira, FA, Jodão, LT (2013) Adubação potássica da soja: Cuidados no balanço de nutrientes. Infor Agronôm. 143:1-10.

Seab - Secretaria da Agricultura e de Abastecimento (SEAB). Custos de produção. Departamento de economia rural. Disponível em: <http://www.agricultura.pr.gov >. Acesso em: 20 jan. 2016

Raij B V (2011) Fertilidade do solo e manejo de nutrientes. Piracicaba. 420 .

Rodrigues MA, Buzetti S, Teixeira Filho MCM, Garcia CMP, Andreatti M (2014) Adubação com KCl revestido na cultura do milho no Cerrado. Rev Bras de Enge Agrí e Amb. 18:127-133.

Rosolem CA, Steiner F (2017) Effects of soil texture and rates of $\mathrm{K}$ input on potassium balance in tropical soil. Europ $\mathrm{J}$ Soil Sci. 68:658-666.

Santiago, AD, Rossetto R (2010) Adubação Mineral. Disponível em: http: // www. agencia. cnptia.embrapa.br/gestor/cana-de açúcar / arvore. Acesso em: 23 dez.2017.

Serafim EM, Ono FB, Zeviani WM, Novelino JO, Silva VJ, (2012) Umidade do solo e doses de potássio na cultura da soja. Revista Ciências Agronômicas. 43:222-227.

Sediyama, T (2009) Tecnologias de produção e usos da soja. Londrina. 314.

Sfredo GJ (2008) Soja no Brasil: calagem, adubação e nutrição mineral. Empresa Brasileira de Pesquisa Agropecuária. Embrapa soja. Londrina: Documento 305, $147 p$.

Siddiqi MY, Glass ADM (1981) Utilization index: A modified approach to the estimation and comparison of nutrient utilization efficiency in plants. J Plant Nutr. 4: 289-302.

Silva AF da, Lazarini E (2014) Doses e épocas de aplicação de potássio na cultura da soja em sucessão a plantas de cobertura. Semina Ciências Agrárias. 35: 179-192.

SBCS- Sociedade brasileira de ciência do solo (2017) Manual de adubação e calagem para o estado do Paraná. 1 a.ed. 482.

Taiz L, Zeiger E (2004). Fisiologia vegetal. 3rd edn, Porto Alegre, 719. 
Urrutia O, Erroj,Zabini A,Hoschiba K,Blandin AF, Baigorri $r$, Martín Pastor M, Alis Y, Yvin JC,Garcia Mina (2018) New amphiphilic composite for preparing efficient coated potassium-fertilizers for top-dressing fertilization of annual crops. J Agric Food Chem.66: 4787-4799.
Vieira BARM, Teixeira MM (2004) Adubação de liberação controlada chega como solução. Revista Campo \& Negócios. 41:4-8.

Zambiazzi EV (2014) Aplicação da adubação potássica na cultura da soja- Dissertação (Mestre)- Programa de pós graduação em agronomia e fitotecnia Lavras. Universidade Federal de Lavras. 